\title{
NEURAMINIDASE PRODUCTION BY CLOSTRIDIA
}

\author{
A. G. Fraser \\ Department of Bacteriology, Medical School, University of Edinburgh, \\ Teviot Place, Edinburgh EH8 $9 A G$
}

THE assay for neuraminidase (EC 3.2.1.18) developed by Fraser and Smith (1975) was used by Fraser and Collee (1975) to investigate the production of the enzyme by a variety of strains of Clostridium perfringens (C. welchii) type A. Sensitive assay procedures were developed that allowed definition of truly neuraminidase-negative strains. Many classical haemolytic strains of $C$. perfringens type A produced neuraminidase and most non-haemolytic foodpoisoning strains did not.

It has been suggested that neuraminidase might play a part in the production of gas gangrene by $C$. perfringens and other clostridia (Collee, 1965b; Gadalla and Collee, 1968; Müller, 1974). Our previous studies of $C$. perfringens have now been extended to investigate the production of neuraminidase by a range of other pathogenic and non-pathogenic clostridia.

\section{MATERIALS AND METHODS}

Bacterial strains. The strains used and their sources are detailed in tables I-III. All strains were held as lyophilised stock, with periodic subculture in cooked-meat broth (CMB) and re-lyophilisation. The source of strains that were recently obtained from the National Collection of Type Cultures, Colindale, London, is shown as NCTC. Other strains were originally obtained from the NCTC and have been held for many years in the collection of Professor J. G. Collee in this department; their NCTC numbers are quoted. The remainder of the strains, including some NCTC strains and clinical isolates from a variety of infections, were obtained from various sources and have been held here, sometimes for many years and with many subcultures. Donors of these strains included Dr Nancy Hayward, Monash University Medical School, Australia, the late Professor C. L. Oakley, Leeds University Medical School, Dr B. Watt, Central Microbiological Laboratories, Western General Hospital, Edinburgh, and colleagues in the diagnostic laboratories in this Department.

For the present studies, all strains were freshly grown in CMB from lyophilised stock and their purity and identity were carefully rechecked in cultural and biochemical studies. Some strains were further checked by immunofluorescence microscopy.

Media and method of anaerobic culture. CMB medium and proteose peptone water broth (PPW5) were prepared as described by Fraser and Smith (1975). The PPW5 broth was clarified by filtering through Whatman no. 1 paper before autoclaving. To improve the growth of strains of $C$. novyi, L-cysteine (Koch Light) and dithiothreitol (BDH) were added (Moore, 1968); the supplemented broth is referred to as PPW5S. A freshly-prepared concentrated $(\times 50)$ solution containing cysteine and dithiothreitol was passed through a membrane filter $(0 \cdot 2-\mu \mathrm{m}$ pore) and added aseptically to the sterile PPW5 broth to give final concentrations of the two substances of $1 \mathrm{mg}$ per $\mathrm{ml}$ and $90 \mu \mathrm{g}$ per $\mathrm{ml}$ respectively; the PPW5S was presteamed and cooled to $37^{\circ} \mathrm{C}$, just before inoculation with the test organism.

Received 24 Nov. 1977; accepted 3 Jan. 1978.

J. MED. MICROBIOL.-VOL. 11 (1978)

269 
Todd Hewitt broth (THB) was prepared according to the manufacturer's recommendations (Oxoid). In early experiments the $p \mathrm{H}$ was adjusted to $7 \cdot 4$ before autoclaving but it was found that the $p \mathrm{H}$ of THB sometimes rose considerably on storage. In later experiments the $p \mathrm{H}$ was adjusted after autoclaving, by the addition of membrane-filtered $1 \cdot 0 \mathrm{M} \mathrm{HCl}$ to the sterile broth before use.

Anaerobic culture methods were as previously described (Fraser and Smith, 1975). Cultures were prepared from lyophilised stock and maintained in CMB medium. An inoculum $(0.1 \mathrm{ml})$ of an overnight anaerobic culture in $\mathrm{CMB}$ incubated at $37^{\circ} \mathrm{C}$ was added to $10 \mathrm{ml}$ presteamed medium and incubated anaerobically at $37^{\circ} \mathrm{C}$ for $48 \mathrm{~h}$. A second serial 48-h culture was made with an inoculum of $0.1 \mathrm{ml}$ from the first 48 -h culture. The purity of growth in the second serial culture was carefully checked. When an organism did not grow or grew very poorly in a particular medium, a further attempt was made with an inoculum of $1.0 \mathrm{ml}$, incubating each serial culture for $96 \mathrm{~h}$.

Growth was estimated visually and recorded as follows: +++ , dense turbidity; ++ , moderate turbidity; + , light turbidity or faint turbidity with many cells seen by microscopy in a wet film; \pm , faint turbidity with few cells present on microscopy;,- no turbidity, or no cells seen on microscopy.

The supernates of the second serial cultures were tested for neuraminidase activity. The cultures were centrifuged $\left(800 \mathrm{~g}\right.$ for $60 \mathrm{~min}$. at $\left.4^{\circ} \mathrm{C}\right)$ and $5-\mathrm{ml} \mathrm{samples}$ of the centrifuged supernates were stored at $-20^{\circ} \mathrm{C}$ before assay. In addition, the centrifuged supernates of C. botulinum cultures were passed through a membrane filter $(0 \cdot 2-\mu \mathrm{m}$ pore) to ensure the removal of all organisms.

Preparation of cell extracts. Cell extracts were prepared from the centrifuged cell deposits of the second serial cultures of a number of strains grown in PPW5 or CMB medium. Cooked-meat particles were allowed to settle and the broth was removed for centrifugation. All the supernate was removed from the packed cell deposit after centrifugation (1200 g for $90 \mathrm{~min}$. at $4^{\circ} \mathrm{C}$ ) and the cells were resuspended in $2 \mathrm{ml}$ sterile normal saline. The resuspended cells were subjected to ultrasonic disintegration for 15-30 min. in an ice bath until the sample was no longer turbid (Fraser and Collee, 1975). These uncentrifuged cell extracts were stored at $-20^{\circ} \mathrm{C}$ until assayed for neuraminidase.

Substrate for neuraminidase assays. Two batches of human glycoprotein substrate FVII (Fraser and Smith, 1975) were used. Batch FVII(6) was used at a final concentration in the 0.5 - $\mathrm{ml}$ test volume of $4.0 \mathrm{mg}$ FVII per $\mathrm{ml}$ as previously (Fraser and Collee, 1975); this batch contained about $4.2 \%$ of $N$-acetyl neuraminic acid (NANA) and the final concentration of releasable NANA in the reaction mixture was thus $c .168 \mu \mathrm{g}$ per $\mathrm{ml}$. The concentration of NANA-rich glycoprotein may vary in different batches of FVII and it is preferable to express the concentration of substrate used in assays in terms of the amount of NANA that can be released from the substrate. Batch FVII(7) was used at a final concentration of $140 \mu \mathrm{g}$ NANA per ml.

Assay for neuraminidase activity. The standard assay was as described by Fraser and Collee (1975). Initial assays for neuraminidase activity in culture products were incubated for $60 \mathrm{~min}$. before assay for free NANA. Test spectrophotometric readings at $549 \mathrm{~nm}$ were corrected by subtraction of the sum of the values for separate enzyme and substrate controls. When the 60-min. assay clearly showed neuraminidase activity, the assay was repeated with a 15 -min. incubation period. When the $60-\mathrm{min}$. assay showed little or no activity, tests were incubated for $24 \mathrm{~h}$ in order to demonstrate the presence or absence of detectable neuraminidase activity.

Tests that gave low corrected spectrophotometric readings $\left(E_{549}\right)$ were further examined with a Pye-Unicam SP8000A spectrophotometer to determine whether the absorption peak was at $549 \mathrm{~nm}$. In order to demonstrate clearly whether a low assay value was or was not due to the presence of NANA, it was occasionally necessary to read the absorption curve of the test mixture against a time-zero $\left(T_{0}\right)$ control test (Fraser and Smith, 1975), rather than the enzyme control, as reference sample.

The corrected results of neuraminidase assays have been graded as follows: +++ , clearly detectable in 15 -min. assays $\left(E_{549}>0 \cdot 1\right) ;++$, low spectrophotometric values in 
15-min. assays $(<0 \cdot 1)$ but NANA release clearly demonstrable in 60 -min. assays; + , not demonstrable in 60 -min. assays but high values $(>0.5)$ in 24 -h assays; \pm , low values $(<0.5)$ in 24-h assays but absorption peak clearly shown at $549 \mathrm{~nm}$; - no peak at $549 \mathrm{~nm}$ demonstrable in 24-h assays.

Tests for the effects of culture products on the NANA assay. Tests to demonstrate whether false negative results might be attributable to destruction of NANA by $N$-acetyl neuraminic acid-aldolase (NAN-aldolase EC 4.1.3.3) were performed on all culture supernates or cell extracts that gave low positive $(+$ or \pm ) or negative results in the 24-h assay for neuraminidase (see Fraser and Smith, 1975). Culture products that did not reduce the assay value for $10 \mu \mathrm{g}$ NANA $\left(E_{549} c .0 .5\right)$ by $0 \cdot 1$ or more during incubation for $24 \mathrm{~h}$ were regarded as having insignificant NANA-destroying activity.

Effect of $\mathrm{Ca}^{2+}$ and EDTA on neuraminidase assays. $\mathrm{CaCl}_{2} \cdot 2 \mathrm{H}_{2} \mathrm{O}(\mathrm{BDH}$, Analar) or EDTA (ethylenediaminetetra-acetic acid disodium salt, BDH, Analar) were added to the acetate buffer used in the neuraminidase assay. The final concentrations of added $\mathrm{Ca}^{2+}$ or EDTA in the reaction mixtures were $3 \mathrm{mM} \mathrm{Ca}^{2+}, 1 \mathrm{~mm} \mathrm{Ca}^{2+}, 1 \mathrm{~mm}$ EDTA or 5mM EDTA. The enzyme preparation $(0 \cdot 1 \mathrm{ml})$ and the acetate buffer containing $\mathrm{Ca}^{2+}$ or EDTA $(0 \cdot 15 \mathrm{ml})$ were mixed and held at $37^{\circ} \mathrm{C}$ for $30 \mathrm{~min}$. before addition of the substrate FVII $(0.25 \mathrm{ml})$ and the start of incubation of the neuraminidase assay. Separate enzyme and substrate control tubes contained the equivalent volumes of acetate buffer in place of the substrate and enzyme respectively. Enzyme control assays also contained the appropriate amount of added $\mathrm{Ca}^{2+}$ or EDTA.

The $C$. perfringens neuraminidase tested was a dialysed preparation (P9D3) of supernate from a bulk culture of strain L2Ab in PPW5 broth (P9) prepared as for the standard preparation (P9D2) used by Fraser and Smith (1975). Vibrio cholerae Receptor-Destroying Enzyme (Wellcome; RDE) was used as $V$. cholerae neuraminidase.

\section{RESULTS}

\section{Neuraminidase production by Clostridium perfringens, Clostridium} septicum, Clostridium chauvoei and Clostridium tertium

Table I gives the data for production of neuraminidase by various strains and species of clostridia examined in this study. Strain L2Ab, a classical neuraminidase-producing strain of $C$. perfringens type $\mathrm{A}$, grew well in both PPW5 and THB media, producing large amounts of neuraminidase in the culture supernates. Cell-associated neuraminidase was also demonstrable with the PPW5 culture, but the enzyme is predominantly extracellular. Good production of neuraminidase was also found in PPW5 culture supernates of strains of $C$. perfringens types $\mathrm{B}, \mathrm{C}, \mathrm{D}$ and $\mathrm{E}$.

The production of large amounts of neuraminidase by strains of $C$. septicum is also easily shown by these techniques and the results for strain NCTC547 are typical of those obtained with other strains of $C$. septicum.

The two strains of $C$. chauvoei tested did not grow well in PPW5 broth and they failed to grow in THB medium. Nevertheleless, strain CC2 produced moderate amounts of neuraminidase in the PPW5 culture supernate. Neuraminidase production by strain NCTC 8070 was demonstrated when the incubation time of the assay was prolonged to $24 \mathrm{~h}$; the enzyme was predominantly extracellular. The low values for neuraminidase activity in the culture supernate and the cell extract were not due to NAN-aldolase activity.

Two strains of $C$. tertium produced small amounts of neuraminidase; more enzyme was produced in PPW5 culture supernates although the organisms grew better in THB medium. 


\section{TABLE I}

Production of neuraminidase by Clostridium perfringens, C. septicum, C. chauvoei, C. tertium, $C$. sordellii and $C$. bifermentans in two broth media

\begin{tabular}{|c|c|c|c|c|c|c|}
\hline \multirow{3}{*}{ Test organism } & \multirow{2}{*}{\multicolumn{2}{|c|}{$\begin{array}{c}\text { Growth in } \\
\text { stated medium* }\end{array}$}} & \multicolumn{3}{|c|}{$\begin{array}{l}\text { Relative amount of neuraminidase } \\
\text { activity in culture product }\end{array}$} & \multirow{3}{*}{$\begin{array}{l}\text { Source of } \\
\text { organism }\end{array}$} \\
\hline & & & \multicolumn{2}{|c|}{ PPW5 } & \multirow{2}{*}{$\begin{array}{c}\text { THB } \\
\text { Culture } \\
\text { supernate }\end{array}$} & \\
\hline & PPW5 & ТНB & $\begin{array}{c}\text { Culture } \\
\text { supernate }\end{array}$ & $\begin{array}{c}\text { Cell } \\
\text { extract }\end{array}$ & & \\
\hline $\begin{array}{l}\text { C. perfringens } \\
\mathrm{L} 2 \mathrm{Ab}\end{array}$ & +++ & +++ & +++ & +++ & +++ & $\begin{array}{l}\text { See Fraser and } \\
\text { Smith (1975) }\end{array}$ \\
\hline $\begin{array}{l}\text { C. septicum } \\
\text { NCTC } 547\end{array}$ & ++ & + & +++ & +++ & +++ & $\begin{array}{l}\text { See Gadalla and } \\
\text { Collee (1967) }\end{array}$ \\
\hline $\begin{array}{l}\text { C. chauvoei } \\
\text { CC2 } \\
\text { NCTC } 8070\end{array}$ & $\begin{array}{l}+\ddagger \\
+\ddagger\end{array}$ & $\begin{array}{l}-\ddagger \\
-\ddagger\end{array}$ & $\begin{array}{l}++ \\
+\end{array}$ & $\dddot{ \pm}$ & $\ldots$ & $\begin{array}{l}\text { Collee } \\
\text { NCTC }\end{array}$ \\
\hline $\begin{array}{l}\text { C. tertium } \\
\text { CTl } \\
\text { NCTC541 }\end{array}$ & + & $\begin{array}{l}++ \\
++\end{array}$ & + & $\begin{array}{l} \pm \\
\ldots\end{array}$ & $\begin{array}{l} \pm \\
\pm\end{array}$ & $\begin{array}{l}\text { Watt } \\
\text { NCTC }\end{array}$ \\
\hline $\begin{array}{l}\text { C. sordellii } \\
1734 \\
\text { P3 } \\
\text { CB2 } \\
\text { CB3 } \\
\text { CB4 } \\
\text { NCTC1340 } \\
\text { NCTC2914 } \\
\text { NCTC6800 } \\
\text { NCTC6801 } \\
\text { NCTC6927 } \\
\text { NCTC6929 } \\
\text { NCTC8780 }\end{array}$ & $\begin{array}{c}+++ \\
+++ \\
+++ \\
++ \\
++ \\
++ \\
+ \\
+ \\
+++ \\
++ \\
++ \\
+++\end{array}$ & $\begin{array}{l}+ \\
+ \\
+ \\
++ \\
++ \\
+ \\
+ \\
++ \\
+ \\
++ \\
++ \\
+\end{array}$ & $\begin{array}{c}+++ \\
+++ \\
+++ \\
+ \\
+ \\
++ \\
+ \\
+ \\
++ \\
+ \\
++ \\
+++\end{array}$ & $\begin{array}{l}\ldots \\
\ldots \\
\ldots \\
\pm \\
\pm \\
\cdots \\
\cdots \\
\ldots \\
\ldots \\
\cdots \\
\cdots\end{array}$ & $\begin{array}{c}+++ \\
+++ \\
+++ \\
+ \\
+++ \\
+++ \\
++ \\
++ \\
++ \\
++ \\
++ \\
+++\end{array}$ & $\begin{array}{l}\text { Oakley } \\
\text { Oakley } \\
\text { Collee } \\
\text { Collee } \\
\text { Watt } \\
\text { NCTC } \\
\text { NCTC } \\
\text { NCTC } \\
\text { NCTC } \\
\text { NCTC } \\
\text { NCTC } \\
\text { NCTC }\end{array}$ \\
\hline $\begin{array}{l}\text { C. bifermentans } \\
\text { B4 } \\
1617 \\
\text { NCTC506 } \\
\text { NCTC1341 } \\
\text { NCTC } 6928\end{array}$ & $\begin{array}{l}+++ \\
+++ \\
+++ \\
++ \\
++\end{array}$ & $\begin{array}{l}+++ \\
+++ \\
++ \\
++ \\
+++\end{array}$ & $\begin{array}{l}\overline{-} \\
\bar{z} \\
\overline{-}\end{array}$ & $\begin{array}{l}- \\
\overline{-} \\
\ldots \\
\ldots\end{array}$ & $\begin{array}{l}\overline{-} \\
\overline{-} \\
-\end{array}$ & $\begin{array}{l}\text { Oakley } \\
\text { Oakley } \\
\text { Collee } \\
\text { NCTC } \\
\text { NCTC }\end{array}$ \\
\hline
\end{tabular}

* See Methods for assessment of growth. PPW5 = Proteose peptone water; THB = Todd Hewitt broth.

$\dagger$ Culture supernate or cell extract from second serial culture in stated medium was tested. See Methods for grading of neuraminidase activity; $\ldots=$ not tested.

‡ 96-h culture; $1 \mathrm{ml}$ inoculum.

\section{Studies with Clostridium sordellii and Clostridium bifermentans}

Most of the 12 strains of $C$. sordellii grew well in PPW5 broth and the supernates of all these cultures contained neuraminidase (table I). These cultures in PPW5 broth gave high enzyme-control readings $\left(E_{549}\right)$ due to the formation of a chromogen with a peak absorption at $530 \mathrm{~nm}$ (Fraser and Smith, $1975)$ and it was occasionally necessary to use a time-zero $\left(T_{0}\right)$ control test as 
reference sample (see Methods). The enzyme was predominantly extracellular in the two strains tested for intracellular enzyme. Several strains grew rather poorly in THB medium but neuraminidase activity was still clearly demonstrable in the culture supernates. Enzyme control values $\left(E_{549}\right)$ were low in THB culture supernates and there was no difficulty in demonstrating the absorption peak at $549 \mathrm{~nm}$ of the chromogen formed in neuraminidase assays.

By contrast, the five strains of the closely related $C$. bifermentans examined could not be shown to produce neuraminidase activity in culture supernates of either medium. The values for enzyme control tests were high in assays with PPW5 culture supernates but comparison with $T_{0}$ control tests confirmed that there was no increase in value in tests incubated for $24 \mathrm{~h}$. No cell-associated enzyme activity was shown in 24-h assays with the cell extracts of PPW5 cultures of three strains. These negative results were shown not to be due to presence of NAN-aldolase activity.

\section{Studies with Clostridium novyi (oedematiens)}

No neuraminidase was demonstrable in cultures of 10 strains of $C$. novyi, types A to D. Table II shows that some strains grew poorly in the test media, although the PPW5 broth was supplemented with cysteine and dithiothreitol (PPW5S), and a large inoculum and prolonged incubation time were used. No

TABLE II

Growth of Clostridium novyi obtained in three fluid media

\begin{tabular}{|c|c|c|c|}
\hline \multirow{2}{*}{ Test organism } & \multicolumn{3}{|c|}{ Growth in stated medium ${ }^{*}$} \\
\hline & PPW5S & THB & CMB \\
\hline \multirow{4}{*}{$\begin{array}{l}\text { Type A } \\
\text { GR2A } \\
\text { GR4A } \\
\text { NCTC538 (GR1A) } \\
\text { NCTC6737 (GR3A) }\end{array}$} & & & \\
\hline & + & ++ & $\ldots$ \\
\hline & + & ++ & $\dddot{\pi}$ \\
\hline & + & $+t$ & $\begin{array}{l}+ \\
\ldots\end{array}$ \\
\hline \multirow{2}{*}{$\begin{array}{c}\text { Type B } \\
\text { GR1B }\end{array}$} & & & \\
\hline & $\pm \dagger$ & $+\dagger$ & + \\
\hline \multicolumn{4}{|l|}{ Type C } \\
\hline $\begin{array}{l}\text { NCTC9746\% } \\
\text { NCTC9747 (GR1C) }\end{array}$ & $\begin{array}{l}+\dagger \\
+\dagger\end{array}$ & $\begin{array}{l}+\dagger \\
+\dagger\end{array}$ & $\ddot{+}+$ \\
\hline \multicolumn{4}{|l|}{ Type D } \\
\hline $\begin{array}{l}\text { NCTC8145 (GR2D) } \\
\text { NCTC } 8350 \text { (GR1D) }\end{array}$ & + & $\begin{array}{l}++ \\
++\end{array}$ & $\ddot{+}$ \\
\hline NCTC $9692 \ddagger$ & ++ & $t+$ & \\
\hline
\end{tabular}

* See Methods for assessment of growth; ... = not tested. PPW5S = Proteose peptone water supplemented with cysteine and dithiothreitol; $\mathrm{THB}=$ Todd Hewitt broth; CMB $=$ cooked-meat broth. (1969).

† 96-h culture; $1 \mathrm{ml}$ inoculum.

$\ddagger$ Source, NCTC. For the source of all organisms, except those marked $\ddagger$, see Rutter and Collee 
neuraminidase activity could be shown in culture supernates in PPW5S or THB media even in assays incubated for $24 \mathrm{~h}$. Culture supernates and cell extracts of four strains grown in CMB medium were also neuraminidase-negative. No significant NANA destruction was found with the majority of these culture supernates or cell extracts; the remainder produced a small reduction in the assay value for NANA after incubation for $24 \mathrm{~h}$, but in no instance was this fall in reading $\left(E_{549}\right)$ greater than $0 \cdot 15$ and this would not have obscured significant neuraminidase activity.

TABLE III

Growth of other neuraminidase-negative clostridia obtained in two broth media

\begin{tabular}{|c|c|c|c|}
\hline \multirow{2}{*}{ Test organism } & \multicolumn{2}{|c|}{ Growth in stated medium* } & \multirow{2}{*}{$\begin{array}{l}\text { Source of } \\
\text { organism }\end{array}$} \\
\hline & PPW5 & THB & \\
\hline $\begin{array}{l}\text { C. tetani } \\
\text { NCTC279 } \\
\text { NCTC540 } \\
\text { NCTC5404 } \\
\text { NCTC5405 } \\
\text { NCTC5413 } \\
\text { NCTC9569 }\end{array}$ & $\begin{array}{l}++ \\
+++ \\
++ \\
++ \\
++ \\
\pm \dagger\end{array}$ & $\begin{array}{l}++ \\
+ \\
++ \\
+ \\
+ \\
+\end{array}$ & $\begin{array}{l}\text { NCTC } \\
\text { Collee } \\
\text { Collee } \\
\text { NCTC } \\
\text { Collee } \\
\text { NCTC }\end{array}$ \\
\hline $\begin{array}{l}\text { C. botulinum } \\
\text { Type A, NCTC7272 } \\
\text { Type B, NCTC7273 } \\
\text { Type C, NCTC3732 } \\
\text { Type E, NCTC } 8266\end{array}$ & $\begin{array}{l}+++ \\
+++ \\
\frac{+}{+}\end{array}$ & $\begin{array}{l}++ \\
++ \\
++ \\
++\end{array}$ & $\begin{array}{l}\text { NCTC } \\
\text { NCTC } \\
\text { NCTC } \\
\text { NCTC }\end{array}$ \\
\hline $\begin{array}{l}\text { C. sporogenes } \\
23 \\
24 \\
26 \\
28\end{array}$ & $\begin{array}{l}+++ \\
+++ \\
+++ \\
+++\end{array}$ & $\begin{array}{l}+++ \\
+++ \\
+++ \\
+++\end{array}$ & $\begin{array}{l}\text { Hayward } \\
\text { Hayward } \\
\text { Hayward } \\
\text { Hayward }\end{array}$ \\
\hline $\begin{array}{l}\text { C. histolyticum } \\
\text { CH2 } \\
\text { NCTC503 } \\
\text { NCTC7123 } \\
\text { NCTC7124 }\end{array}$ & $\begin{array}{l}+++ \\
+++ \\
+++ \\
+++\end{array}$ & $\begin{array}{l}+++ \\
++ \\
+++ \\
+++\end{array}$ & $\begin{array}{l}\text { Collee } \\
\text { Collee } \\
\text { Collee } \\
\text { Collee }\end{array}$ \\
\hline $\begin{array}{l}\text { C. butyricum } \\
\text { NCTC } 7423\end{array}$ & $\pm \uparrow$ & ++ & Collee \\
\hline $\begin{array}{l}\text { C. sphenoides } \\
\text { NCTC507 }\end{array}$ & + & +++ & NCTC \\
\hline $\begin{array}{l}\text { C. fallax } \\
\text { NCTC } 8380\end{array}$ & +++ & ++ & NCTC \\
\hline $\begin{array}{l}\text { C. tetanomorphum } \\
\text { NCTC } 2909\end{array}$ & ++ & +++ & NCTC \\
\hline $\begin{array}{l}\text { C. subterminale } \\
\text { CS1 }\end{array}$ & ++ & +++ & Watt \\
\hline
\end{tabular}

* See Methods for assessment of growth. PPW5 $=$ Proteose peptone water; THB $=$ Todd Hewitt broth.

$\dagger$ 96-h culture; $1 \mathrm{ml}$ inoculum. 


\section{Studies with other neuraminidase-negative clostridia}

Table III shows the other strains of clostridia that did not produce neuraminidase; no activity was demonstrable in 24-h assays in any of the culture supernates. A few strains that grew poorly in one of the test media showed better growth in the other. None of the culture supernates contained significant NANA-destroying activity.

\section{Effect of $\mathrm{Ca}^{2+}$ and EDTA on neuraminidase assays}

Table IV compares the effect of varying the concentration of $\mathrm{Ca}^{2+}$ in the assays of neuraminidase from $C$. perfringens and $V$. cholerae. Assays of pure NANA were not affected by the presence of these amounts of $\mathrm{Ca}^{2+}$ or EDTA. The $V$. cholerae enzyme is very calcium-dependent and its activity in our assay can be almost doubled by the addition of $3 \mathrm{mM} \mathrm{Ca}^{2+}$ to the reaction mixture. By contrast, the activity of the $C$. perfringens enzyme is not increased by the addition of $3 \mathrm{mM} \mathrm{Ca}^{2+}$; 5mM EDTA reduced the assay value by c. $21 \%$ only.

The calcium dependence of the neuraminidase produced by other clostridia was assessed under our standard assay conditions with no added $\mathrm{Ca}^{2+}$ and with added $3 \mathrm{mM} \mathrm{Ca}^{2+}$. Neuraminidase-containing PPW5 culture supernates of the following strains were tested (see table I): C. perfringens L2Ab; C. septicum NCTC547; C. chauvoei CC2 and NCTC8070; C. tertium CT1 and NCTC541; C. sordellii CB3 and NCTC8780. Culture supernates with strong neuraminidase activity were diluted in the acetate buffer before testing in 15-min. assays and the time of incubation of assays of supernates with weak neuraminidase activity was prolonged in order to give assay results in the range $0 \cdot 1-0 \cdot 6$. In no instance was there increased activity in the presence of the added $\mathrm{Ca}^{2+}$.

\section{TABLE IV}

Effect of $\mathrm{Ca}^{2+}$ and EDTA on the assay of neuraminidase from Clostridium perfringens and Vibrio cholerae

\begin{tabular}{c|cc}
\hline $\begin{array}{c}\text { Concentration of added } \mathrm{Ca}^{2+} \text { oDTA in reaction mixture* } \\
\end{array}$ & $\begin{array}{c}\text { Result of neuraminidase assay on stated } \\
\text { preparation }\left(E_{549}\right) \dagger\end{array}$ \\
\hline $3 \mathrm{mM} \mathrm{Ca}^{2+}$ & 0.348 & 0.576 \\
$1 \mathrm{mM} \mathrm{Ca}{ }^{+}$ & 0.315 & 0.436 \\
None added & 0.351 & 0.318 \\
$1 \mathrm{mM}$ EDTA & 0.313 & 0.202 \\
$5 \mathrm{mM}$ EDTA & 0.277 & 0.012 \\
\hline
\end{tabular}

* See Methods.

$\dagger$ The spectrophotometric value $\left(E_{549}\right)$ is an average result obtained from duplicate 15 -min. assay readings corrected by subtraction of the values for the corresponding substrate and enzyme controls. For tested enzyme preparations P9D3 and RDE, see Methods. 
Further tests were performed with the PPW5 and THB culture supernates of C. bifermentans strains B4, NCTC506, NCTC1341 and NCTC6928 that could not be shown to contain neuraminidase in standard assays (see table I). The 24-h assays remained negative in the presence of added $3 \mathrm{mM} \mathrm{Ca}^{2+}$.

\section{Discussion}

The neuraminidase of $C$. perfringens type A was one of the first to be discovered (McCrea, 1947) and has been well characterised (Cassidy, Jourdian and Roseman, 1966). Collee (1965a) reported that the enzyme was also produced by strains of types $\mathrm{B}, \mathrm{C}, \mathrm{D}$ and $\mathrm{E}$ and this was confirmed during the present studies. Although most classical strains of $C$. perfringens type A produce large amounts of neuraminidase, some produce only small amounts and a number of food-poisoning strains are neuraminidase-negative (Fraser and Collee, 1975).

An organism that is shown to produce the enzyme is clearly neuraminidasepositive; it is more difficult to be certain that an organism is truly neuraminidasenegative and can never produce it. The assay procedures developed by Fraser and Collee (1975) to define true neuraminidase-negative strains of $C$. perfringens were used in the present study. Neuraminidase-positive clostridia were shown to produce the enzyme in culture supernates in both PPW5 and THB media although there were often considerable differences in the relative amounts produced and these did not correlate clearly with differences in the relative amounts of growth in the two media. Neuraminidase-negative strains could not be shown to produce the enzyme in either medium, even when assays were incubated for $24 \mathrm{~h}$. Clostridial neuraminidase is essentially extracellular but several neuraminidase-negative strains were further tested to confirm that no cell-associated enzyme could be detected after disruption of the cells.

The $p \mathrm{H}$ optimum of a particular neuraminidase may vary considerably when tested with different substrates (Rafelson, Schneir and Wilson, 1963), with different buffer ions (Cassidy et al., 1966; Fraser and Smith, 1975) or at different ionic strengths (Rosenberg and Schengrund, 1976). Optimal $p \mathrm{H}$ values quoted for bacterial neuraminidases are usually in the range 4.5-6.5 (Drzeniek, 1972); in the present studies, acetate buffer at $p \mathrm{H} 5.1$ was used as this was found to be optimal for $C$. perfringens neuraminidase in earlier studies with FVII substrate (Fraser and Smith, 1975).

Neuraminidases from different sources vary in their calcium dependence and their sensitivity to EDTA (Boschman and Jacobs, 1965; Drzeniek, 1972). C. perfringens neuraminidase is not calcium-dependent (Cassidy et al., 1966) and the present studies showed that the enzyme produced by other clostridial species is also calcium-independent. $\mathrm{Ca}^{2+}$ was not added to our assays as a routine, but culture products of $C$. bifermentans and $C$. novyi retested with the addition of $\mathrm{Ca}^{2+}$ remained negative. It is thus unlikely that our inability to demonstrate neuraminidase production by other clostridia was due to lack of $\mathrm{Ca}^{2+}$ in the reaction mixtures.

The assay for $C$. perfringens neuraminidase may be complicated by the 
presence of NAN-aldolase which may destroy the NANA that is released, but this does not usually prevent detection of quite small amounts of neuraminidase in our assay (Fraser and Collee, 1975). In the present studies, none of the culture products assayed contained sufficient NANA-destroying activity to interfere significantly with the assays for neuraminidase; negative results are thus not attributable to destruction of released NANA by NAN-aldolase.

The clostridial species that produced neuraminidase in the present study were $C$. perfringens, $C$. septicum, $C$. chauvoei, $C$. tertium and $C$. sordellii; all strains tested were neuraminidase-positive. The other clostridial species tested were all neuraminidase-negative.

$C$. septicum and $C$. chauvoei are usually regarded as separate species but the differences between them are very small; Willis (1969) discussed the arguments for regarding them as two types of a single species. Warren and Spearing (1963) noted the presence of neuraminidase activity in a lyophilised preparation of $C$. septicum toxin. Gadalla and Collee (1968) found that the enzyme was produced by all of 15 strains studied. Müller and Schallehn (1972) detected the enzyme in two strains of $C$. chauvoei ( $C$. feseri) by electrophoretic methods. The present study confirmed that strains of $C$. septicum generally produce large amounts of neuraminidase whereas the two strains of $C$. chauvoei produced rather small amounts under the same test conditions.

Howe et al. (1957) reported that $C$. tertium produced an enzyme that destroyed myxovirus receptor substances. Müller and Werner (1974) demonstrated neuraminidase production by a strain of $C$. tertium and the present study confirmed that small amounts of the enzyme were produced by two other strains.

$C$. sordellii and $C$. bifermentans are very closely related and there has been considerable debate as to whether or not they should be regarded as separate species (see Willis, 1969). Pathogenic strains of $C$. sordellii produce the $\beta$-toxin whereas $C$. bifermentans is non-toxigenic, but this is not an adequate criterion for classification as non-toxigenic strains of $C$. sordellii also occur. Nakamura et al. (1975) used numerical taxonomy and DNA homology in a reinvestigation of this problem. They scored for 162 features (not including neuraminidase activity) and concluded that the two species could be reliably differentiated by only a few biochemical tests-fermentation of mannose and sorbitol, urease activity, arginine deamination and growth inhibition by mannose. Warren and Spearing (1963) noted neuraminidase activity in a preparation of $C$. sordellii toxin, and White and Mellanby (1969) separated the neuraminidase from the toxic activity in the culture supernate of a strain of $C$. sordellii. The present finding that all of 12 strains of $C$. sordellii produced neuraminidase but that none of five strains of $C$. bifermentans did so suggests that this may be another character that distinguishes the two species. Soloviev et al. (1972) have suggested that tests for neuraminidase production may be of value in studies of vibrio taxonomy and it now appears that they may also be of interest in certain aspects of clostridial taxonomy.

C. sordellii is a rare cause of wound infection in man and animals (Willis, 1969). The finding that neuraminidase production is one of the few features 
that distinguish this organism from the non-pathogenic $C$. bifermentans might suggest that neuraminidase plays a part in the pathogenicity of $C$. sordellii. White and Mellanby (1969) were unable to show an enhancing effect when $C$. sordellii neuraminidase was added to $\beta$-toxin in guinea-pig skin tests, but they did not study actual infection with the organism.

It has been suggested that neuraminidase may play a part in the pathogenesis of clostridial infections (Collee, 1965 ; Gadalla and Collee, 1968; Müller, $1970 a$ and $b$; Müller and Schallehn, 1972; Fraser and Collee, 1975) although there is little direct evidence for this. Neuraminidase action has been shown to alter a wide range of properties and functions of important proteins and cells (tabulated by Rosenberg and Schengrund, 1976). Müller (1974) reviewed the possible role of neuraminidase in bacterial infections. He argued that there is a correlation between virulence and the ability to produce large amounts of neuraminidase in vivo for a variety of strains and species of bacteria and he suggested that neuraminidase-producing organisms are more likely to be successful in a wide range of infections.

Gadalla and Collee (1968) showed that neuraminidase is produced in vivo during experimental infections with $C$. septicum, and similar findings have been made in tissues taken from guinea-pigs with experimental $C$. perfringens gas gangrene (unpublished results). Müller (1970b) demonstrated changes attributable to neuraminidase in the glycoproteins of the wound exudate from a patient with a $C$. septicum infection and this also shows that neuraminidase is produced and active in vivo.

Neuraminidase might conceivably influence an organisms's invasiveness, or its ability to gain access to a target site or receptor. C. septicum and classical strains of $C$. perfringens type $A$ both produce large amounts of neuraminidase and are important causes of gas gangrene in man, in whom they are invasive pathogens when infection is established. However, C. novyi type A, the other important cause of gas gangrene, is also invasive and is neuraminidase-negative. Of the other neuraminidase-positive species, $C$. chauvoei is pathogenic for animals (blackquarter) but not for man and $C$. tertium is regarded as nonpathogenic. C. tetani and $C$. botulinum, both neuraminidase-negative, are important non-invasive and essentially toxic human pathogens. C. sporogenes, which is closely related to $C$. botulinum, is neuraminidase-negative and essentially non-pathogenic, but $C$. histolyticum and $C$. fallax are neuraminidasenegative histotoxic clostridia with invasive potential. The other clostridia found to be neuraminidase-negative in this study are regarded as non-pathogenic (see Willis, 1969 and 1977).

It is clear that there is no strict correlation between neuraminidase production and the ability of various clostridial species to cause wound infection. However, several pathogenic species produce neuraminidase in addition to recognised toxins and it is possible that this may contribute to their virulence. Further studies are in progress to determine whether there is any correlation between virulence and neuraminidase production in strains of those species that produce the enzyme. 


\section{SUMMARY}

The production of neuraminidase (EC 3.2.1.18) by a range of clostridial species was investigated with techniques previously developed to distinguish neuraminidase-negative and neuraminidase-positive strains of Clostridium perfringens (welchii). Large amounts of extracellular neuraminidase were produced by representative strains of $C$. perfringens and $C$. septicum in the test media. Under similar conditions, two strains each of $C$. chauvoei and $C$. tertium were found to produce small amounts of the enzyme. All of 12 strains of $C$. sordellii were clearly shown to produce neuraminidase, often in large amounts, but none of five strains of the closely related but non-pathogenic $C$. bifermentans had demonstrable neuraminidase activity. No neuraminidase was produced by C. novyi (oedematiens) types A-D (10 strains), $C$. tetani (6), $C$. botulinum types A, B, C or E (4), C. sporogenes (4), C. histolyticum (4) or by single strains of five other clostridial species.

Clostridial neuraminidase was predominantly extracellular and was not calcium-dependent. The investigation took account of variations in growth and enzyme production in different media. It was necessary to prolong the neuraminidase-assay reaction time to $24 \mathrm{~h}$ and to monitor for the presence of NAN-aldolase (EC 4.1.3.3) to define true negatives. It is suggested that neuraminidase production may be of value in taxonomic studies and that its production by several pathogenic species of clostridia may be of interest in studies of pathogenicity and virulence.

The invaluable technical assistance of $\mathrm{Mr}$ Robert Brown and his colleagues and the constant advice and encouragement of Professor J. G. Collee are gratefully acknowledged. I am indebted to Dr J. G. Watt, Scottish National Blood Transfusion Service, Protein Fractionation Centre, Ellen's Glen Road, Edinburgh EH17 7QT for supplies of FVII substrate.

\section{REFERENCES}

Boschman, T. A. C. AND JACOBS, J. 1965. The influence of ethylenediaminetetraacetate on various neuraminidases. Biochem. $Z$., 342, 532.

Cassidy, J. T., Jourdian, G. W. ANd Roseman, S. 1966. Sialidase from Clostridium perfringens. In Methods in enzymology, edited by S. P. Colowick and N. O. Kaplan, New York and London, vol. 8, p. 680.

COLLEE, J. G. 1965a. A myxovirus receptor-inactivating agent occurring in cultures of Clostridium welchii. J. Path. Bact., 90, 1.

COLLEe, J. G. 1965b. The relationship of the haemaggiutinin of Clostridium welchii to the neuraminidase and other soluble products of the organism. J. Path. Bact., 90, 13.

DrzenIEK, R. 1972. Viral and bacterial neuraminidases. Curr. Top. Microbiol. Immun., 59, 35.

Fraser, A. G. AND Collee, J. G. 1975. The production of neuraminidase by food-poisoning strains of Clostridium welchii (C. perfringens). J. med. Microbiol., 8, 251.

Fraser, A. G. AND Smith, J. K. 1975. Preparation of a glycoprotein fraction from pooled human plasma and its evaluation as a substrate for the assay of Clostridium welchii $(C$. perfringens) neuraminidase. J. med. Microbiol., 8, 235.

Gadalla, M. S. A. ANd Collee, J. G. 1967. The nature and properties of the haemagglutinin of Clostridium septicum. J. Path. Bact., 93, 255.

Gadalla, M. S. A. AND ColleE, J. G. 1968. The relationship of the neuraminidase of Clostridium septicum to the haemagglutinin and other soluble products of the organism. J. Path. Bact., 96, 169. 
Howe, C., Maclennan, J. D., Mandl, I. and Kabat, E. A. 1957. Enzymes of Clostridium tertium. Effects on blood group and virus receptor substances. J. Bact., 74, 365.

MCCreA, J. F. 1947. Modification of red-cell agglutinability by $\mathrm{Cl}$. welchii toxins. Aust. J. exp. Biol. med. Sci., 25, 127.

MOORE, W. B. 1968. Solidified media suitable for the cultivation of Clostridium novyi type B. J. gen. Microbiol., 53, 415.

MÜLLER, H. E. 1970a. Die Neuraminidase als pathogenetischer Faktor bei GasödemInfektionen durch Clostridium perfringens. Dt. med. Wschr., 95, 513.

MülLLER, H. E. $1970 b$. The in-vitro identification and the in-vivo action of Clostridium septicum neuraminidase. Zentbl. Bakt. ParasitKde, I. Abt. Orig., 215, 530.

MülLER, H. E. 1974. Neuraminidases of bacteria and protozoa and their pathogenetic role. Behring Institute Mitteilungen, No. 55, p. 34.

MülleR, H. E. AND SchallehN, G. 1972. The occurrence of neuraminidase and acylneuraminate lyase in Clostridium chauvoei (Clostridium feseri). Zentbl. Bakt. ParasitKde, I. Abt. Orig. A, 222, 64.

MüLlER, H. E. AND WERNER, H. 1974. Occurrence of neuraminidase and acylneuraminate lyase in Clostridium beijerinckii and Clostridium tertium. Zentbl. Bakt. ParasitKde, I. Abt. Orig. A, 229, 134.

Nakamura, S., Shimamura, T., Hayashi, H. ANd Nishida, S. 1975. Reinvestigation of the taxonomy of Clostridium bifermentans and Clostridium sordellii. J. med. Microbiol., 8, 299.

RAfelson, M. E. JR, SchneIR, M. AND WILsON, V. W. JR 1963. Studies on the neuraminidase of influenza virus. II. Additional properties of the enzymes from the Asian and PR8 strains. Archs Biochem. Biophys., 103, 424.

Rosenberg, A. AND SCHENGRUND, C.-L. 1976. Sialidases. In Biological roles of sialic acid, edited by A. Rosenberg and C.-L. Schengrund, New York and London, p. 295.

RUtTer, J. M. AND ColleE, J. G. 1969. Studies on the soluble antigens of Clostridium oedematiens (Cl. novyi). J. med. Microbiol., 2, 395.

Soloviev, V. D., Domaradsky, I. V., Shimanyuk, N. Ya., Bichul, K. G. and Kurennaya, I. I. 1972. Function of neuraminidase in Vibrio taxonomy. Bull. exp. Biol. Med. U.S.S.R., 73, No. 2, 61.

WARREN, L. AND SPEARING, C. W. 1963. Sialidase (neuraminidase) of Corynebacterium diphtheriae. J. Bact., 86, 950.

White, A. B. AND MellanBy, J. 1969. The separation of neuraminidase activity from other pathological activities of a culture filtrate of Clostridium sordellii CN 3903. J. gen. Microbiol., 56, 137.

WiLLIS, A. T. 1969. Clostridia of wound infection, London.

WILLIs, A. T. 1977. Anaerobic bacteriology: clinical and laboratory practice, 3rd ed., London. 